\title{
SUSTAINABLE HUMAN RESOURCES MANAGEMENT FROM THE LANGUAGE OF REPORTS
}

\author{
DOI: 10.17261/Pressacademia.2020.1202 \\ RJBM- V.7-ISS.2-2020 (4)-p.95-115 \\ Kubilayhan Goc ${ }^{1}$, Fatma Kusku² \\ ${ }^{1}$ Aksaray University, Department of Business Administration, Aksaray, Turkey. \\ Istanbul Technical University, PhD candidate, Macka, Istanbul, Turkey. \\ gock@itu.edu.tr, ORCID: https://orcid.org/0000-0002-7481-0837 \\ ${ }^{2}$ Istanbul Technical University, Department of Management Engineering, 34367, Istanbul, Turkey \\ kuskufa@itu.edu.tr, ORCID: https://orcid.org/0000-0002-1436-4230
}

Date Received: March 16, 2020

Date Accepted: June 16, 2020

To cite this document

Goc, K., Kusku, F. (2020). Sustainable human resources management from the language of reports. Research Journal of Business and Management (RJBM), V.7(2), p.95-115.

Permanent link to this document: http://doi.org/10.17261/Pressacademia.2020.1202

Copyright: Published by PressAcademia and limited licensed re-use rights only.

\begin{abstract}
Purpose - Although the concept of Sustainable Human Resource Management (HRM) has been frequently discussed in recently, the measurement and dimensions of the concept are still vague. This study aims to explore Sustainable HRM practices and provide a guide to facilitate Sustainable HRM implementations and to measure its pertinent practices.

Methodology - The sample of this study consists of 36 sustainability reports of 29 firms listed on the BIST Sustainability Index. The reports belong to two consecutive fiscal years: 2014-2015 and 2015-2016. The researchers have conducted a content analysis to reports by using the indexing technique, in line with a coding guide adopted from The Global Reporting Initiative - Sustainability Reporting Guidelines-G4 (GRI-G4) principles. Findings- This research has identified the discursive dimension of sustainable HRM in the context of Turkey. Following this purpose, the researchers have prepared a guide and posited the dimensions of Sustainable HRM elaborately. Moreover, the study has demonstrated the applicability of the triple reporting system to the Turkish setting.

Conclusion- Different stakeholder expectations require to take HRM with its macro and micro dimensions. Sustainable HRM stands out as a concept to respond to this demand. After its fast-paced introduction as of 2000 , the concept has gained momentum specifically in the last decade. Conceiving the structure of Sustainable HRM with its economic, environmental, and social dimensions constitutes a critical step of meeting this expectation. This study has identified Sustainable HRM practices, which may guide companies to have a sustainable organizational form and provide researchers a measurement tool.
\end{abstract}

Keywords: Sustainability, human resources management, GRI reports, Borsa İstanbul, Turkey. JEL Codes: J50, O15, M50, M10

\section{INTRODUCTION}

The concept of "sustainability" started to take place in management research as of the 1980s (Dyllick \& Hockerts, 2002). At the outset, sustainability studies, by and large, used to focus on the economic and environmental dimensions ${ }^{1}$ of the concept, whereas, from the 2000 s on, the social dimension (such as moral and ethical values) of sustainability emerged as a vibrant research strand (Kira, 2003; Boudreau \& Ramstad, 2005). Accordingly, the concept of Human Resources Management (HRM) has also become sustainability-oriented, thus elevating the concept of sustainable HRM in the literature (e.g., Zaugg, Blum \& Thom, 2001; Guercini, Pedrini, 2014; Kramar, 2014; Ehnert, Parsa, Roper, Wagner, \& Muller-Camen, 2016). Nevertheless, extant research has

\footnotetext{
1 The environmental dimension includes the use, protection, and development of natural resources. The terms "Green" "Environmental" and" Ecologic" in the sustainability literature are considered synonymously in this study.
} 
focused on one dimension, although economical, environmental, and social dimensions require holistic scrutiny to ensure sustainability entirely (Elkington, 1997). The primary motive of this study is to take these three dimensions seriously.

Along with spreading consciousness of sustainability worldwide, a growing number of organizations have tended to make their activities sustainable. On the other hand, social expectations, which are associated with blending the long-term profitability of the organizations with concepts such as social relations, justice, and environmental protection, arose and increased. This integration prompted the need for building sustainability on certain principles. In this respect, some institutions have engaged in guiding work to achieve sustainability in organizations. Despite these efforts, business organizations faced several problems in performing sustainability activities. Based on the developments in the field and the difficulties experienced by companies, Elkington (1997) stated that the decision-makers should establish auditing mechanisms in their organizations to meet the audience's expectations and market demands. The author further proposed a triple-reporting auditing system to measure sustainability based on economic, environmental, and social dimensions. Meanwhile, in parallel with the developments in the field, the Global Reporting Initiative (GRI) cropped up as a non-profit organization in the USA. The GRI has developed a rubric of reporting principles on corporate sustainability, which cover most of the standards set by global organizations such as the United Nations Global Compact (UNGC), the Organization for Economic Development and Cooperation (OECD), and the International Labor Organization (ILO). Thus, a straightforward reporting mechanism for organizations enabled them to document not only the economic, environmental, and social contributions of organizations but also the effects of organizational activities. Notably, the primary motive was to establish an accountability mechanism for investors.

The triple reporting system aims to expand the stakeholder knowledge on the company and set the principles required to see all the positive/adverse effects of the company activities. Thanks to these reports, firm performance and policies can be put forward qualitatively and quantitatively (Bennett, Bouma, \& Wolters, 2002). Systematically reported information is re-evaluated periodically to ensure the fulfillment of expectations from organizations. When a constraint is reported as the cause of belowsatisfactory results, the firm needs to correct processes that lead to unsustainable results. By so doing, firms can maintain their efforts to achieve their prescribed sustainability goals (Jackson, Boswell, \& Davis, 2011). Such a report gives a message that the transparency of the internal processes will improve, thus eliminating the possible arising concerns among stakeholders due to confidential information (Jackson et al., 2011). Ho and Taylor (2007) emphasize that the company takes more responsibility for reporting, which is an indication of the company accountability in the eye of the stakeholders. In this way, the firm will be able to improve its global reputation. As time elapses, the records show that primarily large-scale companies concentrate their efforts to report their processes (Jackson et al., 2011). Managers' efforts to meet legal requirements, their belief that economic benefits can compensate for relevant costs, or their willingness to demonstrate responsibility for their stakeholders are viewed as the underlying reasons for firms to make more accurate social and environmental statements (Arowoshegbe, Emmanuel, \& Atu, 2016). By sustainability reporting, the constituents who involved in the triple reporting process, including employees and external stakeholders, are able to increase their knowledge about the company and expand their relationship with other stakeholders in the company (Jackson et al., 2011). Reporting on the sustainability of a company sets up a criterion for the future of the companies and enables benchmarking with other companies (Jackson et al., 2011).

Leading global companies recognize the GRI principles as the "actual global standard" for sustainability reporting. Organizations can provide reliable information to their stakeholders. GRI's sustainability reporting guidelines consist of six main categories, namely, economic, environmental, social, product responsibility, human rights and labor practices, and decent work (Ehnert et al., 2016). Two of these categories pertain to Sustainable HRM. The first one is the category of "labor practices and decent work" that aims to reflect the quality of work and the working environment. This category includes nine key performance indicators. The second category includes "human rights" with six key performance indicators. Human rights dwell on issues such as nondiscrimination or the prevention of forced and compulsory labor (GRI, 2014). These prescribed performance indicators apply to the affiliates of the companies in both developing and developed countries (see Ehnert et al., 2016).

In this vein, the sustainability-related reporting systems, based on the GRI reporting principles and performance indicators, are widespread in many countries. These reports, also known as Sustainability Reports, are prepared in various countries by organizations listed on the exchange markets of those countries. Given the Turkish setting, this study has drawn on the implementations by fifteen companies in 2014 reported by the Borsa Istanbul (BIST ${ }^{2}$ ).

${ }^{2}$ BIST is an abbreviation of Borsa Istanbul Joint Stock Company. It is an Exchange in which The Istanbul Stock Exchange (ISE) where the stocks are 
This study aims to reveal the dimensions of Sustainable HRM systematically and, more specifically, to identify the discursive dimension of sustainable HRM fact in Turkey by examining the published reports documented by the BIST. By doing so, the study contributes to the literature by providing a better understanding of the Sustainable HRM and a guide for practitioners while carrying out sustainable HRM activities. The implementation of Sustainable HRM practices will make it more straightforward for companies to have a sustainable organizational form.

The remainder of this study is organized as follows. The next section introduces a conceptual framework of sustainability and Sustainable HRM. The following section articulates the relationship between sustainability and reporting, and elaborates on the methodology. In light of the developed guide, the researchers conducted a content analysis of the sustainability reports in the sample. Afterward, the findings were evaluated, and sustainable HRM practices, which companies declared their implementation, were determined. Finally, the study has created a Sustainable HRM guide discussed the results to explain the concept with all of its dimensions fully.

\section{CONCEPTUAL FRAMEWORK}

\subsection{Sustainability}

Elkington (1997) emphasized three fundamental dimensions of sustainability applicable in the business world and stated that the performance criteria for enterprises should be distributed along "economical," "environmental," and "social" dimensions. In other words, Elkington stated that the principles of integration with the environment, economic prosperity, and social equality should intersect, a violation of which impedes sustainability (Dyllick \& Hockerts, 2002; Bansal, 2005; Wagner, 2013; Ehnert, Harry, \& Zink, 2013). In support of this understanding, the PricewaterhouseCoopers ${ }^{3}$ (2011) report emphasized the need to include economic, environmental, and social variables in all primary, strategic, and operational processes and decision-making mechanisms of firms to ensure sustainability in organizations. In a similar vein, Ingwe, Okoro, \& Ukwayi (2010) conceptualized sustainability as a lifestyle, which supports equality for all aspects of nature and promotes practices related to economic, environmental, and social equality. As time elapsed, social injustice (Neumayer, 2011; Stewart, 2014; Alarcón \& Cole, 2019; Ives, Freeth, \& Fischer, 2020), equal opportunities in resource access (Zink, 2014), intensive consumption of goods and services in industrialized countries, the assurance social and economic development with no adverse effects on natural living conditions (Welford, 2016; Fuchs, 2017; Younis \& Chaudhary, 2019) have been among the main topics discussed in the sustainability literature (Savaneviciene \& Stankeviciute, 2017).

The developments in the dimensions of sustainability can be summarized as follows: According to Brundtland (1987), sustainability situates development discussions into a global framework in which consistent satisfaction of human needs is the ultimate goal. Dyllick and Hockerts (2002), on the other hand, elevated this notion to the business-world level and defined sustainability as the fulfillment of company's internal and external stakeholder (shareholders, employees, customers, pressure groups, communities, and the like) needs without compromising its ability to meet the needs of future stakeholders. For this purpose, firms have to maintain and expand their economic, environmental, and social capital base coupled with political sustainability. Based on this definition, Dyllick and Hockerts (2002) drew attention to three main points in sustainability. First, integrating short-term and longterm aspects; that is, the stock markets stipulate firms focus on short-term gains rather than to establish long-term success. Such an obsession with short-term profits is against the company's spirit of sustainability, which may satisfy the current and future interest of its stakeholders. However, firms may still prefer short-term economic gains to the costs of environmental and social degradation in the long run. The second point pertains to the integration of economic, environmental, and social aspects with the 'triple bottom line'. According to Gladwin, Kennelly, \& Krause (1995) and Elkington (1997), the most critical point where sustainability differs from classical management approaches is the fact that economic sustainability per se does not suffice for a sustainable firm. Dyllick and Hockerts (2002) underlined that a narrow focus on short-term economic sustainability could be successful; however, long-term sustainability needs to be satisfied simultaneously along three dimensions. In addition, since these three dimensions of the "triple bottom line" are interrelated, it is highly likely that they can affect each other in various ways. The third point is the consumption of income rather than capital. The instinct of capital-base protection is a prevailing attitude in the business world and is widely accepted as a prerequisite for successful and responsible business administration. However, to

traded, the Futures and Options Market (VOB) and the Istanbul Gold Exchange (IAB) are united with a contract.

${ }^{3}$ PricewaterhouseCoopers, based in London, a firm providing multinational audit, tax and consultancy services and among the top 4 companies in the world. https://www.pwc.com/ 
achieve long-term sustainability, business people have to manage not only economic capital but also their natural capital ${ }^{4}$ and social capital ${ }^{5}$ (Dyllick \& Hockerts, 2002).

Drawing on these contributions and critiques, some scholars have emphasized that the concept of sustainability encompasses the protection, renewal, and development of a system's economic, environmental and social resources (Senna \& Shani, 2009); thus, companies should manage their impact on economic, environmental and social environments (Mariappanadar, 2003; Ehnert, 2009; Ehnert \& Harry, 2012).

\subsection{Sustainable Human Resources Management}

Extant research shows that (Lees, 1997; Boudreau \& Ramstad, 2005; Boudreau \& Lawler, 2014), efficiency-oriented worries guide the HRM practices in most organizations. In other words, the implementation of HRM activities (selection, training, and development of employees, evaluation of their performance, and the like) aims internal efficiency. Despite its contribution to the organization's efficiency, adhering solely to these HRM activities may harm psychological and social issues related to third parties or stakeholders, such as the well-being of employees, their families, and communities. In a similar vein, some scholars argue that HRM activities have an impact on externalities such as environmental, social, and humanitarian aspects (Mariappanadar, 2003, 2012; Biglan, 2009; Avery \& Bergsteiner, 2011). Primarily, organizational failure to adopt the social cost (material / moral adverse effects it has on society) of its operations and practices may yield undesired outcomes. For example, HRM practices intervene in employees' daily life to achieve organizational goals, thereby forcing them to sacrifice their non-work activities (e.g., leisure time, quality time with family members, and the like) (Greenwood, 2002; Mariappanadar, 2012). The negative external influences have urged further discussions on the concept of Sustainable HRM and led to widening the scope of efficiency-oriented HRM activities. In other words, scholars use the concept of Sustainable HRM as a tool to explain the negative externalities of organizational practices, to ensure an understanding of social issues, and to achieve a sustainable social goal (Mariappanadar, 2012). In the light of the developments mentioned above, Sustainable HRM means the adoption of HRM strategies and practices that not only render economic, environmental and social goals achievable but also provides to control the undesirable side effects and negativities in the long term both inside and outside the institution (e.g., Ehnert, 2009; Kramar, 2014; Ehnert et al., 2016).

According to Kramar (2014), the sustainability studies in HRM literature mainly revolve around three domains. The studies in the first group concentrate on the economic outcomes and sustainable competitive advantage, stressing the capability reproduction activities, and the internal ramifications of the HRM policies (Wilkinson, Hill, \& Gollan, 2001; Wilcox, 2006). The second group of studies focuses on the social and environmental health and emphasizes the visible results (Mariappanadar, 2003; Branco \& Rodrigues, 2006), including broader performance outcomes (environmental and social) primarily. The studies in the last group are called connections (Avery, 2005; Avery \& Bergsteiner, 2011). This group examines the interplay between HRM and managerial practices, and their economic, environmental, and social consequences. Companies view responsibility activities as a moral concern. In other words, the studies in this group examine the interaction between HRM activities and environmental sustainability in terms of various internal and external outputs with a keen consideration of the context.

There are semantic difficulties in establishing sustainability and HRM linkage. Therefore, scholars approach Sustainable HRM with different perspectives and models (Kramar, 2014). The review of Sustainable HRM from different perspectives are summarized in Table 1.

\footnotetext{
${ }^{4}$ Dyllick \& Hockerts (2002) explain natural capital in two ways. The first one is renewable (e.g., wood, fish, corn) or non-renewable (e.g., fossil fuels, soil quality, biodiversity) resources used in economic processes. Secondly, it is defined as tools that serve the ecosystem (e.g., preventing climate change, water treatment, soil improvement, reproduction of plants and animals).

${ }^{5}$ According to Dyllick \& Hockerts (2002), social capital is divided into two as human capital and societal capital. Human capital is about the talent, motivation and loyalty of employees and business partners. Societal capital includes the quality of public services, such as a good education system, infrastructure, or a culture that supports infrastructure and entrepreneurship.
} 
Table 1: Models and Perspectives on Sustainable HRM

\begin{tabular}{|c|c|c|}
\hline Authors & The Focus of the Research & Related Applications \\
\hline Gollan (2000) & $\begin{array}{l}\text { Employee aspirations, needs, and, } \\
\text { potentials should be the primary } \\
\text { concern in the workplace. If there is a } \\
\text { wide gap between the employer } \\
\text { discourse and the workplace reality, } \\
\text { the qualified and enthusiastic } \\
\text { workforce may intend to quit. } \\
\text { Sustainable HRM is a unidimensional } \\
\text { concept. }\end{array}$ & $\begin{array}{l}\text { Work arrangements, technology utilization, } \\
\text { customer/supplier relations, multi-skilling \& job redesign, } \\
\text { production processes (teamwork, total quality } \\
\text { management, training, and appraisal). }\end{array}$ \\
\hline $\begin{array}{l}\text { Zaugg, Blum, } \\
\text { \& Thom, } \\
\text { (2001) }\end{array}$ & $\begin{array}{l}\text { Sustainable HRM is based on three } \\
\text { main goals: increasing employment, } \\
\text { increasing individual responsibility } \\
\text { using participatory leadership systems, } \\
\text { and ensuring an appropriate work-life } \\
\text { balance for employees. There is an } \\
\text { individual-oriented approach. }\end{array}$ & $\begin{array}{l}\text { Employability, promote individual responsibility, work-life } \\
\text { balance. }\end{array}$ \\
\hline Ehnert (2009) & $\begin{array}{l}\text { Sustainable HRM is considered as a } \\
\text { macro and micro level phenomenon. }\end{array}$ & $\begin{array}{l}\text { Micro-level (internal processes): Productivity oriented } \\
\text { practices, cost reduction, efficient and effective resource } \\
\text { deployment, value creation; to make organizational } \\
\text { resources and human resources sustainable, balancing } \\
\text { resource consumption and resource reproduction; } \\
\text { Macro-level (external influence and causes): Responsibility } \\
\text { to society, the need to provide legitimacy, employee } \\
\text { welfare, social welfare, life quality. }\end{array}$ \\
\hline $\begin{array}{l}\text { De Prins } \\
\text { (2011 cited in } \\
\text { Rompa, 2011, } \\
\text { pp. 16-18) }\end{array}$ & $\begin{array}{l}\text { Sustainable HRM has been addressed } \\
\text { based on four different perspectives. } \\
\text { In this way, it focuses on establishing a } \\
\text { strong relationship between } \\
\text { organizational strategy and } \\
\text { environment, utilizing efficiently from } \\
\text { and approaching respectfully to the } \\
\text { organizational workforce. }\end{array}$ & $\begin{array}{l}\text { Psychological perspective: Stimulate dialogue with the } \\
\text { employees, Support employees in their work-life balance, } \\
\text { engage employees in decisions that affect them, policies } \\
\text { targeted at the prevention of stress, flexible working } \\
\text { opportunities, educational support; } \\
\text { Sociological perspective: diverse workforce, employees' } \\
\text { health, and safety, volunteer work, engagement policies, } \\
\text { family-friendly personnel policies; } \\
\text { Strategic perspective: recruitment, employee turnover, } \\
\text { employee appraisal, and employability; } \\
\text { Green perspective: eco - friendly employee behavior, green } \\
\text { employer branding, environmental awareness training, } \\
\text { promotion of environmentally sustainable behavior }\end{array}$ \\
\hline Kramar (2014) & $\begin{array}{l}\text { The outcomes of Sustainable HRM can } \\
\text { be measured by evaluating individual, } \\
\text { organizational, social, and ecological } \\
\text { outcomes. HRM processes have } \\
\text { negative and positive effects on } \\
\text { different stakeholders. }\end{array}$ & $\begin{array}{l}\text { Organizational outcomes: Quality of employment } \\
\text { relationship, health and well-being of the workforce, and } \\
\text { organizational productivity; } \\
\text { Individual outcomes: Job satisfaction, motivation, work-life } \\
\text { balance, organizational commitment, turnover rate; } \\
\text { Social outcomes: being recognized among a range of } \\
\text { potential sources of labor, being an employer of choice, the } \\
\text { quality of relationships at work; } \\
\text { Ecological outputs: Awareness in the use of resources such } \\
\text { as energy, paper, water; production of environmentally } \\
\text { friendly products and services; reduction of business travel- }\end{array}$ \\
\hline
\end{tabular}




\begin{tabular}{|c|c|c|}
\hline \multicolumn{3}{|r|}{ related costs. } \\
\hline $\begin{array}{l}\text { De Prins, } \\
\text { Beirendonck, } \\
\text { De Vos, \& } \\
\text { Segers (2014) }\end{array}$ & $\begin{array}{l}\text { Sustainable HRM is a form of } \\
\text { personnel management, which } \\
\text { respects the workforce and strikes a } \\
\text { balance among the interests of } \\
\text { employers, employees, and society. In } \\
\text { the study, the "Respect, Openness, } \\
\text { and Continuity (ROC)" model facilitates } \\
\text { the implementation and dissemination } \\
\text { of Sustainable HRM practices. }\end{array}$ & $\begin{array}{l}\text { Respect (seeking people in HRM): Talent, employee loyalty, } \\
\text { empowerment, health and well-being, employee } \\
\text { participation; } \\
\text { Openness (HRM from the outside): Diversity (diversity } \\
\text { management), the aging workforce, work-life balance, } \\
\text { environment, stakeholders, labor market; } \\
\text { Continuity (Long-term perspective): Employability, career, } \\
\text { succession, learning organizations, workplace innovation. }\end{array}$ \\
\hline $\begin{array}{l}\text { Järlström, } \\
\text { Saru, \& } \\
\text { Vanhala } \\
\text { (2016) }\end{array}$ & $\begin{array}{l}\text { A four-dimensional sustainable HRM } \\
\text { model has been introduced, including } \\
\text { justice and equality, transparent HRM } \\
\text { practices, profitability, and employee } \\
\text { well-being. Despite its broad scope, } \\
\text { the study neglected environmental } \\
\text { responsibility. }\end{array}$ & $\begin{array}{l}\text { Justice \& equality: Diversity management, ethical values, } \\
\text { exemplary behavior of managers, and obeying laws and } \\
\text { regulations; } \\
\text { Transparent HR practices: Recruitment and allocation of } \\
\text { human resources, competence development, rewarding, } \\
\text { career planning, employee participation, and open two-way } \\
\text { communication, flexibility, and individuality (working hours, } \\
\text { leaves, rewards, distance work, holidays, retirement); } \\
\text { Profitability: Integration of organizational strategies and } \\
\text { HRM, proactiveness in actions, long-term thinking, } \\
\text { HR/managers' knowledge/experience; } \\
\text { Employee well-being: Preventing the exploitation of the } \\
\text { employees, meeting their physical and mental demands, } \\
\text { preventing the damage of the business relations of the } \\
\text { employees with their managers and colleagues. Leadership } \\
\text { style of managers (approachable, trustable, motivating) }\end{array}$ \\
\hline $\begin{array}{l}\text { Tabatabaei, } \\
\text { Omran, } \\
\text { Hashemi, \& } \\
\text { Sedaghat } \\
\text { (2017) }\end{array}$ & $\begin{array}{l}\text { A Sustainable HRM model is proposed } \\
\text { based on the Balanced Scorecard. The } \\
\text { model focuses on economic and social } \\
\text { practices. }\end{array}$ & $\begin{array}{l}\text { Learning and growth perspective: Purposeful HR training } \\
\text { and development, long-life learning, equal opportunity, } \\
\text { equal opportunity for individual's growth; } \\
\text { Internal process perspective: Developing sustainable } \\
\text { working systems (developing human resources and raising } \\
\text { new ones, protecting them from poor working conditions), } \\
\text { fair reward systems, and motivating incentives compatible } \\
\text { with sustainability goals, change toward sustainability, } \\
\text { ensuring the training of human resources. } \\
\text { Stakeholder perspective: Dialogue spaces for stakeholders, } \\
\text { increasing employability, health and safety of human } \\
\text { resources, work-life balance, control of negative } \\
\text { externalities of HRM; } \\
\text { Value creation perspective: Organizational reputation, } \\
\text { social legitimacy, sustainable competitive advantage, } \\
\text { increased productivity, and lastly, attraction and retention } \\
\text { of skilled, motivated, and committed HR. }\end{array}$ \\
\hline
\end{tabular}

\section{METHODOLOGY}

Having aimed to explore the sustainable HRM practices in the Turkish setting and reveal the dimensions of the concept, this study has drawn its sample from the sustainability reports of the focal firms. The sampling frame of the study consists of the firm reports that conform to the BIST Sustainability Index between 2014 and 2016. The selection criteria are threefold. First, the companies quoted on the Borsa Istanbul are institutionalized organizations. Second, these organizations are obliged to document their activity reports and sustainability reports transparently. Third, also most importantly, they are subject to the Sustainability index appraisals established in BIST in 2014. All combined, these features evince that they take the issue of "sustainability" more 
seriously than other business enterprises. Accordingly, fifteen companies in the 2014-20156 period and twenty-nine companies in the 2015-2016 period were audited and included in the BIST sustainability index. While some companies published their sustainability reports online, others documented the report content in web sites to the target audiences under different headings. However, some organizations' reports were not available. Under these constraints, thirty-six available reports have constituted the sample of this study.

The research was carried out in two stages: In the first stage, the GRI G4 Sustainability Guidelines were examined in terms of "HRM" and a "Sustainable HRM practices guide" was created for analysis. In the second stage, the sustainability reports were subjected to content analysis in line with the guide created, and the data were digitilized by the indexing method.

In the content analysis, the textual meanings are systematically and objectively determined by unfolding their communicative aspects (Prichard, Jones, \& Stablein, 2004). To achieve this procedure, a researcher gathers similar data under certain concepts and themes and presents it to the reader in an understandable way. While doing so, the initial step is data codification. Having examined the coded data, the researcher tries to divide them into meaningful sections/categories (Campopiano \& De Massis, 2015) such as words, sentences, or paragraphs (Insch, Moore, \& Murphy, 1997; Neuman, 2007). In this respect, Strauss and Corbin (1990) articulate three types of coding methods (cited in Yıldırım \& Şimşek, 2016, pp. 244-246): The codification according to predetermined concepts, the data-driven codification, and the coding in a general framework.

Given that this study relies on a sustainability guide, the first method applies to this study. Accordingly, each of the standardized Global Reporting Initiative principles was examined one by one, and all variables that may be related to Human Resources Management were considered as "Sustainable Human Resources Management" variables according to several keywords, codes, and meanings. Based on this procedure, the researchers have defined the Sustainable Human Resources Management along the economic, environmental, and social dimensions with a total of thirty-two variables. While classifying each item (by word, code, and meanings), the researchers assigned each variable to the most appropriate category. In case a bilateral representation potentially leads to confusion, the researchers omitted the variable from the coding, which increased the category validity (Insch et al., 1997).

Accordingly, all HRM-related variables, which constitute one of the economic variables specified in the Sustainability Guide, are considered as variables representing the "Economic Dimension of Sustainable Human Resources Management" according to several keywords, codes, and meanings (Table 2). A similar procedure was followed for the environmental and social variables. In sum, the researchers have identified the variables that represent the "Environmental Dimension of Sustainable Human Resources Management" (Table 3) and "Social Dimension of Sustainable Human Resources Management" (Table 4).

Table 2: Words, Codes, and Meanings Representing Economic Dimension

\begin{tabular}{|c|c|}
\hline Sub dimensions and indicators & Code and Meanings \\
\hline \multicolumn{2}{|c|}{ Employee-oriented expenses (Rewarding / Remuneration) } \\
\hline 1.Employee wages $(\mathrm{G} 4-\mathrm{EC} 1)^{7}$ & $\begin{array}{l}* \text { EC1 (code) * Employee salaries * Retirement salaries * Dismissal } \\
\text { payments *Insurance Payments }\end{array}$ \\
\hline 2.Fringe benefits (G4- LA2) & $\begin{array}{l}\text { *LA2 (code), * Benefits, * Life Insurance, * Health Care, } \\
\text { *Retirement right, *Disability and invalidity coverage *Stock } \\
\text { ownership *Housing, *Interest-free loans, *Public transport } \\
\text { assistance, *Educational grants, and *Redundancy payments. }\end{array}$ \\
\hline $\begin{array}{l}\text { 3.Employer-provided retirement } \\
\text { plan (G4-EC3) }\end{array}$ & $\begin{array}{l}\text { *EC3 (code), }{ }^{*} \text { Retirement plans, }{ }^{*} \text { Individual Retirement, * } \\
\text { Compensation plans }\end{array}$ \\
\hline $\begin{array}{l}\text { 4.Offering wages above the } \\
\text { minimum wage (G4-EC5) }\end{array}$ & $\begin{array}{l}\text { * EC5 (code), * Local Minimum wage, * Entry level wage, * Salary, * } \\
\text { Wage }\end{array}$ \\
\hline
\end{tabular}

\footnotetext{
${ }^{6}$ The date of preparation and first audit of the sustainability reports

${ }^{7}$ The measurement statements specified in the table are based on the Global Reporting Initiative (GRI) G4 Guidelines. For example, the meaning of the code 'G4-EC1' in the guideline is explained as "economic value created and distributed". Codes and meanings are the units that facilitate the scanning of variables in the report.
} 


\begin{tabular}{ll}
\hline $\begin{array}{l}\text { 5.Employee protective arrangements } \\
\text { and expenses (G4-EC2) }\end{array}$ & $\begin{array}{l}* \text { EC2 (code), * Climate * Risk management, * effect on the } \\
\text { workforce (e.g., the effect on health: temperature-related } \\
\text { discomfort and diseases, *The necessity to change operation } \\
\text { locations }\end{array}$ \\
\hline Society oriented expenses & \\
\hline $\begin{array}{l}\text { 6.Voluntary donations, investments } \\
\text { for the benefit of the society (G4- } \\
\text { EC1) }\end{array}$ & $\begin{array}{l}* \text { EC1 (code), *Voluntary * Volunteering, * Donation, * Grant, * } \\
\text { Charities, * Events }\end{array}$ \\
\hline
\end{tabular}

Table 3: Words, Codes, and Meanings Representing Environmental Dimension

\begin{tabular}{ll}
\hline Sub dimensions and indicators & \multicolumn{1}{c}{ Code and Meanings } \\
\hline $\begin{array}{l}\text { 1. Protecting the natural environment } \\
\text { (G4- EN13) }\end{array}$ & $\begin{array}{l}{ }^{*} \text { EN13 (code) * Partnerships, * Protection, * Habitat, * Nature, * Organizing and } \\
\text { directing human resources to environmental activities, *habitats that are under } \\
\text { the protection of the organization or which the organization has restored }\end{array}$ \\
\hline $\begin{array}{l}\text { 2. Raising employee awareness (G4- } \\
\text { EN6-9-19) }\end{array}$ & $\begin{array}{l}{ }^{*} \text { EN6, * EN9, * EN19 (code), *Organizations' policies to get green } \\
\text { (environmentalist) behavior to their employees, *energy and water use and } \\
\text { *reduction of emissions }\end{array}$ \\
\hline 3. Avoiding harm (G4-EN34) & $\begin{array}{l}* \text { EN34 (code), * Dialogue with local external stakeholders, *Grievances, *Conflict, } \\
\text { *Environmental impact }\end{array}$ \\
\hline
\end{tabular}

Table 4: Words, Codes, and Meanings Representing Social Dimension

\begin{tabular}{|c|c|c|}
\hline \multicolumn{2}{|c|}{ Sub-dimensions and indicators } & Code and Meanings \\
\hline \multicolumn{3}{|c|}{ Performance Indicators Related to the Quality of Work Environment } \\
\hline \multirow{10}{*}{$\begin{array}{l}\text { Basic Human } \\
\text { Rights }\end{array}$} & $\begin{array}{l}\text { 1- Investment contracts compatible with } \\
\text { human rights articles (G4- HR1) }\end{array}$ & *HR1 (code), *Human rights \\
\hline & 2- Prevention of child labor (G4- HR5) & ${ }^{*}$ HR5 (code) *Child Labor, *Human Rights \\
\hline & $\begin{array}{l}\text { 3- Prevention of forced or compulsory } \\
\text { labor (G4- HR6) }\end{array}$ & $\begin{array}{l}\text { HR6 (code), *Forced labor, *Compulsory labor, *Child Labor, } \\
\text { *Human Rights }\end{array}$ \\
\hline & $\begin{array}{l}\text { 4- The existence of a grievance mechanism } \\
\text { on human rights (G4- HR12) } \\
\end{array}$ & $\begin{array}{l}{ }^{*} \mathrm{HR} 12 \text { (codes), }{ }^{*} \text { Local community, }{ }^{*} \text { Complaint }{ }^{*} \text { Grievance } \\
\text { mechanism }\end{array}$ \\
\hline & $\begin{array}{ll}5- & \text { Evaluation of human rights activities } \\
\text { (G4- HR12) }\end{array}$ & * HR12 (code), * Human Rights, * Evaluation, *Assessment \\
\hline & $\begin{array}{l}\text { 6- Maternity and Paternity Leave (G4- LA3) } \\
\text { (G4- LA3) }\end{array}$ & *LA3 (code), *Maternity leave, *Paternity leave \\
\hline & $\begin{array}{l}\text { 7- } \text { Compliance with minimum notice } \\
\text { periods regarding operational changes } \\
\text { (G4-LA4) }\end{array}$ & * LA4 (code), *Operational changes, *Notice periods \\
\hline & $\begin{array}{l}\text { 8- } \text { Right to freedom of association and } \\
\text { collective bargaining (G4- HR4) }\end{array}$ & * HR4 (code), *Collective Bargaining, *Association \\
\hline & $\begin{array}{l}\text { 9- Suppliers' efforts to prevent negativities } \\
\text { in labor practices (G4- LA15) }\end{array}$ & $\begin{array}{l}\text { *LA15 (code), *Supplier, *Health and Safety Practices, } \\
\text { *Mobbing, *Industrial Relations, *Wages and other payments, } \\
\text { *Working Hours, *Employment practices, *Evaluation, }\end{array}$ \\
\hline & $\begin{array}{l}\text { 10- Labor practices grievances mechanism } \\
\text { (G4- LA16) }\end{array}$ & *LA16 (code), *Complaint, *Grievances *Business ethics \\
\hline $\begin{array}{l}\text { Occupational } \\
\text { Health and } \\
\text { Safety }\end{array}$ & $\begin{array}{l}\text { 11- Occupational health and safety } \\
\text { committees formed with the } \\
\text { participation of employees (G4- LA5) }\end{array}$ & $\begin{array}{l}\text { *LA5 (code), *Occupational health and safety, *Committee } / \\
\text { Team, *Responsibility, *Participation }\end{array}$ \\
\hline
\end{tabular}




\begin{tabular}{|c|c|c|}
\hline & $\begin{array}{l}\text { 12- Evaluation of health and safety cases } \\
\text { (G4- LA6-7) }\end{array}$ & $\begin{array}{l}\text { *LA6-LA7 (code), *Deaths, *Accident frequency rate, } \\
\text { *Occupational disease rate, }{ }^{*} \text { Lost Day rate, } * \text { Absenteeism rate, } \\
\text { *Occupational accident rate, }{ }^{*} \text { Injury, *Serious diseases }\end{array}$ \\
\hline & $\begin{array}{l}\text { 13- Contracts with unions cover health and } \\
\text { safety issues (G4-LA8) }\end{array}$ & ${ }^{*}$ LA8 (code), *Union, ${ }^{*}$ Health and Safety *Contract \\
\hline \multirow{2}{*}{$\begin{array}{l}\text { Diversity } \\
\text { Management }\end{array}$} & 14- Workforce diversity (G4- LA12) & $\begin{array}{l}\text { *LA12 (code), }{ }^{*} \text { Gender, }{ }^{*} \text { Position, }{ }^{*} \text { Age group, }{ }^{*} \text { Nationality, } \\
{ }^{*} \text { Minority etc. }{ }^{*} \text { Classification of employees according to } \\
\text { different variables }\end{array}$ \\
\hline & $\begin{array}{l}\text { 15- Equal remuneration for men and } \\
\text { women (G4- LA13) }\end{array}$ & $\begin{array}{l}\text { *LA13 (code), *Salary, *Wage / Remuneration, *Equality, } \\
\text { *Gender }\end{array}$ \\
\hline \multirow{2}{*}{$\begin{array}{l}\text { Social } \\
\text { Relations }\end{array}$} & $\begin{array}{l}\text { 16- Operations with local community } \\
\text { engagement (G4-SO1) }\end{array}$ & *SO1, *Participation, *Stakeholder Meetings \\
\hline & $\begin{array}{l}\text { 17- Violation of the rights of the local } \\
\text { community (G4- HR8) }\end{array}$ & *HR8 (code), *Local community, *violations \\
\hline \multicolumn{3}{|c|}{ Performance Indicators Related to Staffing } \\
\hline & $\begin{array}{l}\text { 1- Employee turnover and characteristics } \\
\text { of new hires (G4- LA1) }\end{array}$ & $\begin{array}{l}{ }^{*} \text { LA1 (code), }{ }^{*} \text { Distribution of new hires by age, gender and } \\
\text { regions, }{ }^{*} \text { Employee turnover, }{ }^{*} \text { Recruitment, }{ }^{*} \text { Employee leaving }\end{array}$ \\
\hline & $\begin{array}{l}\text { 2- Employment from the local community } \\
\text { to senior management (G4-EC6) }\end{array}$ & * EC6 (code), *Local, *Employment, *Governance \\
\hline \multicolumn{3}{|c|}{ Performance Indicators Related to Employee Development } \\
\hline & $\begin{array}{l}\text { 1- Offering employees with training and } \\
\text { education opportunities (G4- LA9) }\end{array}$ & *LA9 (code), *Education rates, *Education, *Training \\
\hline & $\begin{array}{l}\text { 2- Lifelong learning opportunity for } \\
\text { workforce continuity (G4-LA10) }\end{array}$ & $\begin{array}{l}\text { *LA10 (code), *Career, *Talent Management, *Lifelong } \\
\text { learning, *Support, *Courses, *Educational Opportunities, } \\
\text { *Paid study permits }\end{array}$ \\
\hline & $\begin{array}{l}\text { 3-Regular performance and career } \\
\text { development evaluation (G4- LA11) }\end{array}$ & $\begin{array}{l}\text { *LA11, *Performance Evaluation, *Performance Management } \\
\text { *Career }\end{array}$ \\
\hline & $\begin{array}{l}\text { 4- Training employees in human rights } \\
\text { policies and procedures (G4 HR2- HR7) }\end{array}$ & *HR2, *HR7 (code), *Human Rights, *Education \\
\hline
\end{tabular}

As a result, the economic dimension, the environmental dimension, and the social dimension, with its three sub-dimensions, included six, three, and twenty-three variables, respectively. Following the Global Reporting Initiative (GRI) standards, the researchers have identified these variables as representing human resources.

Drawing on the guidance presented in Table 2, Table 3, and Table 4, the researchers conducted a content analysis of all reports in the sample. While digitizing the content analysis, the researchers have applied the indexing technique, which, as a popular method, measures the extent of adherence to GRI indicators (see Parsa \& Kouhy, 2008; Ehnert et al., 2016). Accordingly, the specified variables are scored based on a precise rule. The scoring process took place on a dual basis. For each variable, the "1" score was assigned if it was mentioned in whole or in part, and "0" if it was not mentioned. Some firms provided additional information such as "not reported," "not disclosed," and "not applicable" if they did not refer to the relevant items. Such expressions were also counted as "not disclosing" and assigned as " 0 " points. A comparable score was then calculated for each of the relevant Sustainable HRM variables. The calculated score was obtained by dividing the total score of the variable that was reported by the companies to the highest possible score (Parsa \& Kouhy, 2008; Ehnert et al., 2016).

$$
\text { Calculated Score }=\frac{\text { the total score of the variable reported actually }}{\text { the highest potential score }} \times 100
$$

The reliability of the content analysis depends on the reliability of the coder and coding categories (Creswell \& Clark, 2011). Intercoder reliability means that two different coders code the same content similarly, or the same coder recodes the same content similarly in a different period and shows excellent consistency. The reliability of the categories pertains to the precise definition and exposition of the categories. The two stated reliabilities are closely related, and if the categories are not defined reliably, the coders will have low reliability. Insch, et al., (1997) state, in this regard, that the reliability of the content classification 
varies according to the registration units. According to the authors, a given study that concentrates on specified words and expressions has higher reliability than a study that uses paragraphs as the unit of analysis.

The analysis units were systematically explained in Table 2, Table 3, and Table 4 to strengthen the reliability of the report review in this study. During the classification of the data and content analysis, reliability concerns were tried to be minimized by mostly using codes, words, and expressions. Comparison/repeatability opportunities were created for future studies with the guidelines prepared for the examination of sustainability reports. Thus, the study aimed at a high level of reliability. Creating such guidelines increases reliability due to the use of the same categories and rules (Insch et al., 1997).

The first author's codings based on the guidelines have yielded 95\% and 94\% of consistency for 2014-2015 and 2015-2016, respectively. During the second coding round, a different coder has coded according to the same guide. The coder responses in a matrix form and the checks of response-compatibility enabled to compare the results of the two rounds. The comparison denoted $91 \%$ and $85 \%$ of compatibility for 2014-2015 and 2015-2016, respectively. The conflicting responses became reevaluated after a meeting with the second author to reexamine them. After further assessment, the compliance increased to $95 \%$ and $90 \%$ for the focal temporal brackets.

Qualitative data sampling requires qualitative validity, which can be measured by comparing data from different sources (e.g., transcripts and images) or different individuals. If the inferences drawn from existing texts are based on inferences, comments, or texts from previous studies, content analysis is valid (Creswell \& Clark, 2011; Krippendorff, 2004). Weber (1990) defines the face validity in the content analysis as the conformity between the definitions of the researcher and the categories used to measure them. Since GRI provides standardized and detailed guidelines for reporting, companies are not allowed to make excessive subjective evaluations in their reports (Ehnert et al., 2016). This ensures that the superficial validity of the study is high. Semantic validity is that coding units make similar semantic associations (Weber, 1990). Persons familiar with the subject have semantic validity if they put the coding units in terms of language and meaning in the same categories. Based on the GRI principles, categories, and coding units, we can talk about an external compromise in the categories and code units of the guides created accordingly, which is considered sufficient for semantic validity.

\section{FINDINGS AND DISCUSSIONS}

Table 5 exhibits the distribution of the reporting rates for economic, environmental, and social dimensions of Human Resource Management related topics of Sustainability reports belonged to the periods of 2014-2015 and 2015-2016. An overall interpretation of the table shows that the representation of all three dimensions in the reports is satisfactory. However, the rate of the companies reporting in the 2014-2015 period to include variables that address human resources (85.22\%) is higher than the $2015-2016$ period $(80 \%, 95)$. This shows that firms provided more detailed data/evaluations during the first reporting periods. Of course, an important issue that should also be emphasized here is that the reports do not prove the desired level of implementations of these practices in focal companies. To understand whether the company practices are at the desired levels, instead of discourse that represents employer insights, one should take into account employee opinions about practices.

Table 5: Reporting rates of Sustainable HRM dimensions in GRI Reports

\begin{tabular}{llcc}
\hline \multicolumn{2}{l}{ Sustainability Dimensions Reported by Companies } & $\mathbf{2 0 1 4 - 2 0 1 5 ~ ( \% ) *}$ & 2015-2016 (\%)* \\
\hline Economic & Quality of Work Environment & 97,16 & $\mathbf{7 5}$ \\
\hline \multicolumn{2}{l}{ Environmental } & 74,66 & 84,35 \\
\hline \multirow{3}{*}{ Social } & Staffing & 87,24 & 64,5 \\
\cline { 2 - 4 } & Employee Development & 70,5 & 91,75 \\
\hline & & 93,75 & 80,95 \\
\hline
\end{tabular}

\section{Findings within the Scope of Economic Dimension}

"Economic dimension" embraces various economic support and investments by the organization in favor of its stakeholders. Six performance indicators of the economic dimension are associated with human resources management. These indicators can be 
divided into 8 "employee-oriented" and "society-oriented" (See Table 6). Firms report their situation within the framework of these indicators. As can be understood from the findings, the firms reporting for the first time presented more detailed data/evaluations within this scope. While the economic indicators expressed in the reports for the period of 2014-2015 are $97.16 \%$ on average, this rate decreases to $85 \%$ for the $2015-2016$ period (See Table 5).

Table 6: Basic Performance Indicators Regarding Economic Dimension

\begin{tabular}{lcc}
\hline Economic Dimension and HRM & 2014-2015 (\%)* & 2015-2016 (\%)* \\
\hline Employee-oriented expenses (Rewarding / Remuneration) & & 96 \\
\hline Employee Wages (G4-EC1) & 100 & 92 \\
\hline Fringe benefits (G4- LA2) & 100 & 63 \\
\hline Employer-Provided Retirement Plan (G4-EC3) & 100 & 67 \\
\hline Offering wages above the minimum wage (G4-EC5) & 100 & 92 \\
\hline Employee protective arrangements and expenses (G4-EC2) & & 96 \\
\hline Society-oriented expenses & 100 & 96 \\
\hline Voluntary donations, investments for the benefit of society (G4-EC1) & & 9 \\
\hline
\end{tabular}

An employee-oriented economic performance indicator, "wages, side benefits, and supports provided by the organization to its employees" (e.g., pensions, insurance, company vehicles, private health insurance, public transport aids, educational scholarships, housing benefit) is an indicator of economic well-being and essential factor that increases employees' intention to stay in the company (Freitas, Jabbour, \& Santos, 2011;Mariappanadar \& Kramar, 2014; Cleveland et al., 2015). Another economic activity carried out on behalf of the employees is "offering wages above the minimum level." Providing wages above the minimum level will strengthen the relationship between the organization and society, ensure loyalty for employees, and attract potential employee candidates to the organization. The minimum wage is also a factor that positively affects the validation of organizational activities by society (Chapman, Uggerslev, Carroll, Piasentin, \& Jones, 2005; Cleveland et al., 2015; Vihari \& Rao, 2018). Sustainable firms will try to make a payment above the minimum wage, by which employees can meet their basic needs (e.g., food, shelter, service, clothing, health, and education) and maintain their lives in a dignified way. Another performance indicator evaluated accordingly is the provision of a pension plan for employees. Thus, employees will be able to live without worry about their longterm economic well-being. This will be a source of a reputation for the company (Chapman et al., 2005; Vihari \& Rao, 2018) and will make employees more productive in the workplace (Cleveland et al., 2015). The latest performance indicator considered in this context is to protect employees against various changes. Within the scope of sustainability, organizations are also expected to carry out protective and remedial activities from the adversities of climate changes in their work environments, and hence employees. Such activities include practices/precautions and expenses to reduce the adverse effects (temperature-related illnesses and diseases) of climate change on employee health and other adverse effects of changing the locations of activities. According to the researches, due to the activities that the companies will perform in this context, the employees view their companies as attentive, kind, and helpful (Hur, Moon, \& Choi, 2019), which leads to an increase in their motivation and organizational commitment.

By taking the employee-oriented performance indicators in economic dimension holistically, the following situation emerges: The explanations on the wages, benefits, and support provided to the employees and investments to protect the employees have been very high in the reports in both periods, and this can be considered as a very satisfactory situation. The rate of firms reporting for the other two indicators (paying above the minimum level and providing a pension plan) related to employees was significantly lower than the reporting made for other indicators, especially in the second period. In other words, the number of companies offering their employees a pension plan and trying to show that they pay more than the minimum wage is extremely low. This situation causes employees to have difficulties in meeting basic living standards.

The other performance indicator in the economic dimension is society-oriented and generally related to the corporate social responsibility activities of organizations. Social responsibility activities are expressed as optional practices of an organization targeting at different stakeholder groups to ensure social welfare (Hur et al., 2019). The voluntary donations, support, and grants made by the organization and its employees to external factors (e.g., non-governmental organizations, charities, funds for the

${ }^{8}$ This distinction was created in this working process. There is no such distinction in the GRI system 
development of social infrastructure, social programs, arts, and education activities) evaluated within this scope are expenses focused on the development of the society. Opportunities for employees to gain practical experience in sustainability initiatives significantly increase not only their knowledge but also their interest and commitment to sustainability (Haugh \& Talwar, 2010). Social responsibility activities of the companies for the external environment ensure that the employees are proud of the company of which the right image maintain in the society (Hur et al., 2019). Increasing the level of respect for employees for their institutions may lead to a more robust corporate identity understanding (Hameed, Riaz, Arain, \& Farooq, 2016). Voluntary donations and investments made by institutions for the benefit of the society have been very high in the reports in both periods, and of course, this can be considered as a satisfactory situation.

As it is evaluated generally, it is understood that firms are sensitive about transferring resources for social activities. Expenses for voluntary investments for the benefit of the society is encouraged by the state through various mechanisms (e.g., deducting the expenses from taxes to be paid). Naturally, in the emergence of this result, there could be a significant share of that is being promoted.

\section{Findings within the Scope of Environmental Dimension}

The review of the HR literature has yielded several HR variables under the dimensions of Protecting the Natural Environment, Employee Awareness, and Avoiding Harm, which indicates the use of the natural environment and its resources (Wagner, 2011; Muster \& Schrader, 2011; Sivamoorthy, Nalini, \& Kumar, 2013; Marpa \& Juele, 2016). The reason for the grouping is that the environmental principles in the guide mostly include terms and statistical expressions outside the HRM field.

Table 7: Basic Performance Indicators Related to Environmental Dimension

\begin{tabular}{lcc}
\hline Environmental Dimension and HRM & 2014-2015 (\%)* & 2015-2016 (\%)* \\
\hline Protecting the natural environment (G4- EN13) & 58 & 71 \\
\hline Raising employee awareness (G4-EN6-9-19) & 83 & 79 \\
\hline Avoiding harm (G4-EN34) & 83 & 83 \\
\hline
\end{tabular}

Whether in the field in which the organization operates or not, the programs, which aim natural habitat protection and giving the least harm to the environment by using environmental resources balanced and efficient, can facilitate the legitimacy of the organization (Wagner, 2011). Marpa \& Juele (2016) states that natural and human-centered disasters have become worse with people's unconscious behavior, and it is not possible to eliminate such disasters. The authors go on to state that the basis of minimizing the negative impact of people on nature is to create awareness through education, and they emphasize that environmental awareness in individuals is an expectation of our zeitgeist. Sivamoorthy, Nalini, \& Kumar (2013), on the other hand, advocate that raising awareness among individuals per se does not suffice; beyond that, environmental awareness should be supported with environmentally friendly practices. The GRI principles draw attention to this issue. Accordingly, while conducting its activities, the organization should be aware of the importance of the water and energy it uses for the local community and prepares programs to raise employee awareness. Another critical issue is the programs that are intended for reducing harmful gases and emissions to avoid environmental damage. Reducing emissions and greenhouse gases are regulated by the "United Nations Framework Convention on Climate Change" and "Kyoto Protocol". As a result, various incentives and rewards are offered by the states. Turkey's climate change policy in this context was regulated with Turkey Climate Change Strategy ${ }^{9}$ (2010-2023) and Turkey National Climate Change Action Plan ${ }^{10}$ (2011-2023) documents. Environmental activities are essential for public health, so they contribute to the organizational reputation.

Generally speaking, this dimension was reported less about Human Resources Management when compared with the economic and social dimensions. Similar situations also arise in report reviews in other countries (e.g., Vanderstraeten, 2015). This is so because Sustainable HRM is generally considered as a socio-economic issue by companies (Kramar, 2014), and environmental issues are approached as a technical issue. Therefore, environmental indicators are often specified in reports by presenting numerical data (e.g., carbon footprint, greenhouse gas emission) and not associated with human resource management activities.

${ }^{9}$ See. https://www.gmka.gov.tr/dokumanlar/yayinlar/Turkiye-Iklim-Degisikligi-Stratejisi.pdf

${ }^{10}$ See. http://www.dsi.gov.tr/docs/iklim-degisikligi/ideptr.pdf?sfvrsn=2. 


\section{Findings within the Scope of the Social Dimension}

In the literature, the variables (such as employee recruitment, training, rights, work safety and health, representation, behaviors towards employees, working environment conditions), which Sustainability and Human Resources Management are mostly associated with, are gathered under this dimension. This dimension is evaluated in this study with 23 indicators in total within the sub-dimensions of "Quality of Work Environment," "Staffing," and "Employee Development" to establish a healthier relationship with HRM functions. The reporting rates of performance indicators determined according to the GRI guide, which we consider under these three dimensions, are given in Table 8.

Table 8: Basic Performance Indicators Related to Social Dimension

\begin{tabular}{|c|c|c|}
\hline & 2014 & 2015 \\
\hline \multirow[t]{2}{*}{ Sub Dimensions } & 2015 & 2016 \\
\hline & (\%) & (\%) \\
\hline \multicolumn{3}{|l|}{ Performance Indicators Related to the Quality of Work Environment } \\
\hline \multicolumn{3}{|l|}{ Basic Human Rights } \\
\hline Investment contracts compatible with human rights articles (G4- HR1) & 83 & 83 \\
\hline Prevention of child labor (G4- HR5) & 100 & 79 \\
\hline Prevention of forced or compulsory labor (G4- HR6) & 92 & 75 \\
\hline The existence of a grievance mechanism on human rights (G4- HR12) & 92 & 100 \\
\hline Evaluation of human rights activities (G4- HR12) & 83 & 79 \\
\hline Maternity and Paternity Leave (G4- LA3) & 92 & 88 \\
\hline Compliance with minimum notice periods regarding operational changes (G4-LA4) & 58 & 46 \\
\hline Right to freedom of association and collective bargaining (G4- HR4) & 83 & 83 \\
\hline Suppliers' efforts to prevent negativities in labor practices (G4- LA15) & 100 & 92 \\
\hline Labor practices grievances mechanism (G4- LA16) & 100 & 100 \\
\hline \multicolumn{3}{|l|}{ Occupational Health and Safety } \\
\hline $\begin{array}{l}\text { Occupational health and safety committees formed with the participation of employees (G4- } \\
\text { LA5) }\end{array}$ & 100 & 100 \\
\hline Evaluation of health and safety cases (G4- LA6-7) & 92 & 96 \\
\hline Contracts with unions cover health and safety issues (G4- LA8) & 75 & 79 \\
\hline \multicolumn{3}{|l|}{ Diversity Management } \\
\hline Workforce diversity (G4- LA12) & 100 & 100 \\
\hline Equal remuneration for men and women (G4- LA13) & 100 & 100 \\
\hline \multicolumn{3}{|l|}{ Social Relations } \\
\hline Operations with local community engagement (G4-SO1) & 100 & 92 \\
\hline Violation of the rights of the local community (G4- HR8) & 33 & 42 \\
\hline \multicolumn{3}{|l|}{ Performance Indicators Related to Staffing } \\
\hline Employee turnover and characteristics of new hires (G4- LA1) & 83 & 83 \\
\hline Employment from the local community to senior management (G4-EC6) & 58 & 46 \\
\hline \multicolumn{3}{|l|}{ Performance Indicators Related to Employee Development } \\
\hline Offering employees with training and education opportunities (G4- LA9) & 100 & 100 \\
\hline Lifelong learning opportunity for workforce continuity (G4-LA10) & 100 & 100 \\
\hline Regular performance and career development evaluation (G4- LA11) & 100 & 100 \\
\hline Training Employees in Human Rights Policies and Procedures (G4 HR2- HR7) & 75 & 67 \\
\hline
\end{tabular}

\section{Quality of Work Environment}

A pleasant work environment should offer competitive wages, ensure trust and cooperation between employees and managers, adopt the idea of equality and justice for everyone, and provide employees with achievable goals and reasonable workload 
(Agbozo, Owusu, Hoedoafia, \& Atakorah, 2017). Work environments have physical, psychological, and social aspects, which are intertwined. Issues such as the office designs, occupational health, and safety are physical; factors that affect how employees feel are psychological; factors covering human rights, such as discrimination based on age, gender or racial past, and sexual harassment, are the social environment subjects. Thus, the work environment accommodates sustainable organizations in which not only social sensitivities but also physical and psychological employee-health are among primary concerns. On the other hand, focusing on the factors considered in the GRI principles, the quality of the work environment can be evaluated with four sub-titles as regulations on fundamental human rights, occupational health and safety, diversity management, and social relations.

An alignment between essential human rights and organizational activities appears as a strategy to reduce the investment risk of the organization. According to Ehnert et al., (2016), the reputation of an organization, whose records are contaminated with human rights violations, may be damaged, thus negatively affecting stakeholder investment. Wong (2017) states that the protection of human rights from a Sustainable HRM perspective is essential for ensuring the firm's social legitimacy. On the contrary, he states that it will leave an impression of a negative organizational image in society. In support of both authors, Cahaya \& Hervina (2019) state that global stakeholders expect companies to demonstrate good human rights behaviors (e.g., the right to organize and collective bargaining, policies against child labor), and as a result, firms will both make economic profits (attracting investors) and guarantee to be sustainable. It means that they will gain and also be sustainable.

For this reason, Cahaya \& Hervina (2019) state that making investment agreements on human rights issues and working with companies that have undergone human rights reviews is an important measure. It is seen that the reporting on this subject, except for a single performance indicator, is quite satisfying in both periods, slightly more satisfactory in the first period. The fact that the reporting is deficient on "Complying with the minimum notice periods related to the activity changes" appears to be alarming.

Performance indicators of occupational health and safety are related to the elimination or reduction of health problems and occupational risks that workers are exposed to due to the physical environmental conditions in the workplace (Agbozo et al., 2017). OSHA (2016) states that employers can be genuinely sustainable only when they ensure the safety, health, and well-being of their employees. Establishing committees with managers and employees together makes it easier to establish and improve the health and safety culture in the organization (Haugh \& Talwar, 2010; Hirsig, Rogovsky, \& Elkin, 2014). Otherwise, when the employees experience a severe injury that will cause long-term absenteeism in the workplace, the employees will not be able to be replaced easily, which will cause the companies to experience a significant decrease in their productivity (Hirsig et al., 2014). Also, official agreements between unions and firms on health and safety help to create a positive health and safety culture within the organization due to bilateral binding. In this context, although the reporting is generally very high in both periods, it is seen that reporting on the performance indicator of "Contracts with unions covers health and safety issues" is significantly lower. This case, unfortunately gradually (Erikli, 2018; Kağnıcığlu \& Etci, 2019; Palaz \& Poyraz, 2019) can be interpreted as a result of increasing rates of non-unionization in the business life in Turkey.

Workforce diversity gives information about the human capital of the organization. Gender wage equality is vital for keeping qualified employees in the organization. In cases of wage inequality, the organization loses its reputation and may face legal sanctions based on discrimination. Successful diversity management may lead to high levels of employee creativity and problemsolving capability (Mazur, 2015). It is pleasing to see that companies have made detailed reports on this issue.

As a reflection of the importance of companies for the development of a country, "operations carried out with local community participation" and "violations of the rights of the local community" are evaluated within the scope of social relations. The interests of different stakeholder groups are frequently brought to fore within the definitions of sustainability. For example, Tabatabaei et al., (2017) express sustainability as an effort to establish a constructive, continuous and purposeful communication between the organization and other parties, placing importance on the interests of different stakeholder groups. Similarly, Arreola (2015) states that a strong relationship with society should be established to prevent social violations, to manage the existing and potential effects of organizational activities on the local community, to determine social expectations and needs. Cahaya \& Hervina (2019) states that the earnings they achieved by violating the rights of the local community threaten the sustainability of the companies. Although the reports contain a vast amount of information on "operations with local community involvement", there is quite a little information on "violation of the rights of the local community". According to Tarquinio, Raucci, \& Benedetti (2018), firms emphasize such indicators less in their reports, as the state takes several measures (e.g., laws, standards, audits) against human rights violations. 


\section{Staffing}

As economies increasingly rely on knowledge, the demand for qualified staff is increasing (Ehnert \& Harry, 2012). "Employee turnover and characteristics of new hires" are expressed as an indication of how skilled organizations attract qualified staff (See App, Merk \& Büttgen, 2012). However, demographic factors such as the aging population and low birth rate restrict the employability of skilled employees needed for the company's sustainable competitive advantage (Lis, 2012; Mak, Cheung, Mak, \& Leung, 2014). Sustainability offers HRM a new way to tackle such challenges. For example, a study conducted in the USA by Renwick et al., (2016) shows that job seekers are more interested in environmentally supportive jobs, and many prefer greenfriendly employers. However, this raises the question of "is the situation so innocent as it seems?" Because if the company can spend money on environmental concerns, it means that it can provide employees more wages and benefits (Ehnert, Harry, \& Zink, 2013). It is seen that in both period reports about the employee turnover rate and the characteristics of new hires, given information is about $80 \%$.

Another indication for staffing is "employment from the local community to senior management". In the society in which firms operate, the employment of the local community to the senior management will significantly improve the relations between the organization and the society; thus, mutual needs will be easily identified. Cohen et al., (2012) express the employment of international companies from the local community as an indicator of loyalty towards that society. Thus, employees familiar with the culture and business processes of that region join the company. Local employment also promotes business continuity, lowers costs, and enables building relationships with local stakeholders. Reporting on this issue is at a low level in both periods. The reason for this, even though they have foreign partners, can be expressed that almost all of the reporting organizations are Turkeycentered.

\section{Employee Development}

Scholars state that firms must provide their employees with learning opportunities and support them to generate new ideas to ensure sustainability (Klein, 2004; Harry, 2014). In support of this, Tabatabaei et al., (2017) described the training of human resources as a new injection of blood into the veins of the organization. This allows employees to adapt to the changing environment. Education is a fundamental task for organizations and is a continuous and permanent process that should be maintained throughout the life of individuals (Ehnert, 2009). By engaging in training, performance evaluation, and career management processes, companies ensure that employees contribute to the organization's strategic goals. Within the scope of training employees at work, evaluating their performance, and managing careers, there are satisfactory data/evaluations in the reports in both periods. However, it can not be said that the explanations in the reports on "Providing training to employees on human rights policies and procedures" are sufficient. This lack seems to be a reflection of the overall emphasis given to human rights in Turkey (Graham \& Woods, 2006; Kuzey \& Uyar, 2017).

\section{CONCLUSION}

As a face-paced domain, Sustainable HRM has attracted scholarly interest, which aims to contribute to the literature by analyzing institutional sustainability reports that may prove useful to publicly demonstrate the extent of a firm's desire sustainable HRM (Ehnert et al., 2016). In light of these insights, this study has concentrated on firms quoted to BIST Sustainability Index in the Turkish setting, revealed how much space they allocated for Sustainable HRM practices in their reports, and explored the extent of their sustainability implementations. The study has followed such a method based on the premise that extracting HRM practices from sustainability reports contributes to our understanding of Sustainable HRM structure and practices.

In this study, a content analysis was carried out under the guidance of GRI principles by grouping HRM-related practices under economic, environmental, and social dimensions. Such categorization efforts are considered to be the most appropriate way of validity and reliability in terms of reviewing sustainability reports systematically and making comparisons in future studies (Insch, 1997; Creswell \& Clark, 2011; Neuman, 2007; ilgar \& ilgar, 2013).

Although the data related to economic, environmental, and social dimensions are widely used in sustainability reports, the use of these three dimensions is not very common in HRM and sustainability literature (Ehnert et al., 2016). Scholars usually address a single dimension of sustainability and overlook the remaining two dimensions (Ehnert et al., 2013; Guerci \& Pedrini, 2014; Ehnert et al., 2016; De Prins, Stuer, \& Gielens, 2018 'social dimension'; Wagner, 2013; Paillé, Chen, Boiral, \& Jin, 2014; Ahmad, 2015 'environmental dimension'; Ehnert, 2009; App et al., 2012 'economic dimension'). As discussed before, in line with the 
recommendation of Elkington (1997), this study has undertaken a more comprehensive evaluation by taking into account economic, environmental, and social dimensions.

Moreover, this study has divided the time frame into two temporal brackets while analyzing firm sustainability reports in Turkey. The reporting rates for the period 2014-2015 are 83.83\% for HRM-related social indicators, 97.16\% for HRM-related economic indicators, and $\mathbf{7 4 . 6 6 \%}$ for HRM-related environmental indicators. To determine the reliability of the study, the sustainability reports for the 2015-2016 period were included into the analysis, and despite being slightly lower than the first reporting period, the reporting rate was over $75 \%$ for every three dimensions $(80.20 \%$ for HRM-related social indicators, $85 \%$ for HRM-related economic indicators and $77.66 \%$ for HRM-related environmental indicators).

The study by Ehnert et al., (2016) explored only the social dimension of the GRI principles (labor force/employment, human rights, and society) employing the sustainability reports of 2010 of 138 Forbes companies. However, their scope of analysis on sustainable HRM practices was very narrow. The measured rates are slightly lower, yet close to those in Ehnert et al., (2016) (the rate of information in the reports is $73.7 \%$ for indicators related to Labor/Employment, $65.9 \%$ for human rights indicators, and $71.9 \%$ for Society related indicators). The authors interpreted that Sustainable HRM practices do not lag behind economic and environmental practices, which means that companies do not neglect Sustainable HRM practices. Compared to the data of companies in FORBES Global (USA, UK, Canada, Australia, European countries, such as Japan), we advocate that firms in Turkey do not neglect Sustainable HRM practices.

Not surprisingly, the HRM practices in the social dimension are reported at a high rate, given that they represent the essential functions of traditional HRM. The high rate of reporting of economic and environmental HRM practices seems to reflect contemporary trends. Economic HRM practices aim for employee well-being, whereas environmental HRM strives to develop environmental awareness and increase legitimacy.

This study has deemed the existing classifications in the literature insufficient and re-grouped performance variables in the GRI reports within the scope of "HRM." Thus, it tries to unfold the link between HRM and Sustainability principles. While doing this, we have adhered to the triple bottom line (Elkington, 1997), which is viewed as an indispensable part of sustainability. The HRM activities are comprehensively included since Sustainable HRM has expanded the boundaries of traditional HRM (Mariappanadar, 2003; Ehnert, 2009; Ehnert et al., 2013; Ehnert et al., 2016).

Among the performance indicators included in the concept of sustainability, those related to HRM can be summarized as in figure 1. This demonstration summarizes the basic dimensions of the Sustainable HRM concept.

Figure 1: Sustainable HRM Structure

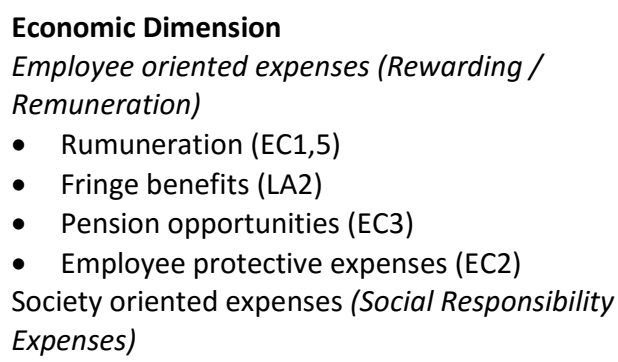

- Social responsibility expenses outside the organization (EC1)

\section{Environmental Dimension Awareness of employees}

- Environmental policy of the organization and what has been done in this context, in order to give employees environmentalist behavior $(E N 6,9,19)$ Protection of Environmental Resources

- Protecting the natural environment (EN13)

Avoiding Harm

- Avoiding environmental harm (EN34)

\section{Social Dimension}

The Quality of Work Environment

- Basic human rights (HR1,4,5,6,12-LA3,4,15,16)

- Occupational health and safety $(L A 5,6,7,8)$

- Diversity management (HR3-LA12,13)

- Social relations (SO1-HR8) Staffing

- HR procurement and selection (LA1-EC6)

Employee Development

- Education and training (LA9,10-HR2,7)

- Performance evaluation and career planning (LA10,11) 
The economic dimension of Sustainable HRM consists of two main sub-dimensions: "Employee Oriented Activities" and Society Oriented Activities. The first sub-dimension means the economic value that companies offer directly for their employees, such as employee wages, benefits, and supports, retirement opportunities, and protective investments. The second sub-dimension is investments that do not directly affect company employees. It includes expenses such as grants, supports, volunteering activities etc. carried out by companies out of the organization. The environmental dimension of sustainable HRM encompasses variables, including the development of eco-friendly behavior for employees, the elevation of employee awareness, the protection of environmental resources, the introduction of grievance mechanisms to prevent environmental damage. The social dimension of sustainable HRM is addressed in three sub-dimensions: Quality of Work Environment, Staffing, and Employee Development. The safe, fair, and humane work environment is discussed under the sub-heading of "Quality of Working Environment". The recruitment activities potential job candidates are discussed under the subheading of "Staffing". Education, training, career planning, and performance evaluation variables, which concern both the professional and personal careers of the employees, are discussed under the sub-heading "Employee Development".

As seen in Figure 1, we think that the internal and external roles of Sustainable HRM can be understood more straightforwardly. Scholars may use this demonstration as a guide to compare data of different years/countries, while practitioners can use it as a guide to help them conduct sustainable HRM activities in their businesses.

\section{REFERENCES}

Agbozo, G. K., Owusu, I. S., Hoedoafia, M. A., \& Atakorah, Y. B. (2017). The Effect of Work Environment on Job Satisfaction: Evidence from the Banking Sector in Ghana. Journal of Human Resource Management, 5(1), 12-18. https://doi.org/10.11648/j.jhrm.20170501.12

Ahmad, S. (2015). Green Human Resource Management: Policies and practices. Cogent Business \& Management, 2(1), 1-13. https://doi.org/10.1080/23311975.2015.1030817

Alarcón, D. M., \& Cole, S. (2019). No sustainability for tourism without gender equality. Journal of Sustainable Tourism, 27(7), 903-919. https://doi.org/10.1080/09669582.2019.1588283

App, S., Merk, J., \& Büttgen, M. (2012). Employer Branding: Sustainable HRM as a Competitive Advantage in the Market for High Quality Employees. Management Revue, 23(3), 262-278. https://doi.org/10.1688/1861-9908

Arowoshegbe, A. O., Emmanuel, U., \& Atu, O. G. (2016). Sustainability and Triple Bottom Line: An Overview of Two Interrelated Concepts. Igbinedion University Journal of Accounting, 2(August), 88-126.

Arreola, O. G. (2015). Learning From Theories and Practice Of Sustainability: In Search of Cohesion. Doctoral Dissertation. Michigan State University.

Avery, G. (2005). Leadership for Sustainable Futures: Achieving success in a competitive world. Edward Elgar Publishing.

Avery, G. C., \& Bergsteiner, H. (2011). Sustainable Leadership : Honeybee and Locust Approaches. Routledge.

Bansal, P. (2005). Evolving sustainably: A longitudinal study of corporate sustainable development. Strategic Management Journal, 26(3), 197218. https://doi.org/10.1002/smj.441

Bennett, M., Bouma, J. J., \& Wolters, T. (Eds.). (2002). Environmental Management Accounting: Informational and Institutional Developments (Vol.9). Springer Science \& Business Media.

Biglan, A. (2009). The role of advocacy organizations in reducing negative externalities. Journal of Organizational Behavior Management, 29(3-4), 215-230. https://doi.org/10.1080/01608060903092086

Boudreau, J., \& Lawler, E. E. (2014). Stubborn traditionalism in HRM: Causes and consequences. Human Resource Management Review, 24(3), 232-244. https://doi.org/10.1016/j.hrmr.2014.03.005

Boudreau, J. W., \& Ramstad, P. M. (2005). Talentship talent segmentation, and sustainability: A new hr decision science paradigm for a new strategy definition. Human Resource Management, 44(2), 129-136. https://doi.org/10.1002/hrm.20054

Branco, M. C., \& Rodrigues, L. L. (2006). Corporate social responsibility and resource-based perspectives. Journal of Business Ethics, 69(2), 111132. https://doi.org/10.1007/s10551-006-9071-z

Brundtland. (1987). Our Common Future, From One Earth to One World (The Brundtland Report). Report of the World Commission on Environment 
and Development. https://doi.org/10.1080/07488008808408783

Cahaya, F. R., \& Hervina, R. (2019). Do human rights issues matter? An empirical analysis of Indonesian companies' reporting. Social Responsibility Journal, 15(2), 226-243. https://doi.org/10.1108/SRJ-10-2016-0171

Campopiano, G., \& De Massis, A. (2015). Corporate Social Responsibility Reporting: A Content Analysis in Family and Non-family Firms. Journal of Business Ethics, 129(3), 511-534. https://doi.org/10.1007/s

Chapman, D. S., Uggerslev, K. L., Carroll, S. A., Piasentin, K. A., \& Jones, D. A. (2005). Applicant attraction to organizations and job choice: A metaanalytic review of the correlates of recruiting outcomes. Journal of Applied Psychology, 90(5), 928-944. https://doi.org/10.1037/00219010.90 .5 .928

Cleveland, J. N., Byrne, Z. S., \& Cavanagh, T. M. (2015). The future of HR is RH: Respect for humanity at work. Human Resource Management Review, 25(2), 146-161. https://doi.org/10.1016/j.hrmr.2015.01.005

Cohen, E., Taylor, S., \& Muller-Camen, M. (2012). HRM's Role in Corporate Social and Environmental Sustainability. SHRM Report, 1, 1-16.

Creswell, J. W., \& Clark, V. L. P. (2011). Designing and Conducting Mixed Methods Research (2nd Editio). California: SAGE Publications.

De Prins, P., Beirendonck, L. Van, De Vos, A., \& Segers, J. (2014). Sustainable HRM: Bridging theory and practice through the 'Respect Openness Continuity (ROC)'-model. Management Revue, 25(4), 263-284. https://doi.org/10.1688/mrev-2014-04-Prins

De Prins, P., Stuer, D., \& Gielens, T. (2018). Revitalizing social dialogue in the workplace: the impact of a cooperative industrial relations climate and sustainable HR practices on reducing employee harm. International Journal of Human Resource Management, 5192, 1-21. https://doi.org/10.1080/09585192.2017.1423098

Dyllick, T., \& Hockerts, K. (2002). Beyond the business case for corporate sustainability. Business Strategy and the Environment, 11(2), 130-141. https://doi.org/10.1002/bse.323

Ehnert, I. (2009). Sustainable Human Resource Management : A conceptual and exploratory analysis from a paradox perspective. Contributions to Management Science. Physica-Verlag HD.

Ehnert, I., \& Harry, W. (2012). Recent Developments and Future Prospects on Sustainable Human Resource Management. Management Revue, 23(3), 221-238.

Ehnert, I., Harry, W., \& Zink, K. J. (Eds.). (2013). Sustainability and Human Resource Management - Developing Sustainable Business Organizations. Springer Science \& Business Media.

Ehnert, I., Parsa, S., Roper, I., Wagner, M., \& Muller-Camen, M. (2016). Reporting on sustainability and HRM: a comparative study of sustainability reporting practices by the world's largest companies. The International Journal of Human Resource Management, 27(1), 88-108. https://doi.org/10.1080/09585192.2015.1024157

Elkington, J. (1997). Cannibals With Forks: The Triple Bottom Line of 21st Century Business. Oxford: Capstone Publishing Limited.

Erikli, S. (2018). Türkiye'de Sendikaların Durumu ve Yeni Misyon Arayışları. International Journal of Labour Life and Social Policy, 1(1), $18-25$.

Freitas, W. R. S., Jabbour, C. J. C., \& Santos, F. C. A. (2011). Continuing the evolution: Towards sustainable HRM and sustainable organizations. Business Strategy Series, 12(5), 226-234. https://doi.org/10.1108/17515631111166861

Gladwin, T. N., Kennelly, J. J., \& Krause, T.S. (1995). Shifting Paradigms for Sustainable Development: Implications for Management Theory and Research. Academy of Management Review, 20(4), 874-907. https://doi.org/10.5465/amr.1995.9512280024

Gollan, P. (2000). Sustainability: The Corporate Challenge of the 21st Century. (D. Dunphy, J. Benveniste, A. Griffiths, \& P. Sutton, Eds.). Sydney: Retrieved from https://books.google.com/books?id=ihx-XAygf8MC\&pgis=1

Graham, D., \& Woods, N. (2006). Making corporate self-regulation effective in developing countries. World Development, 34(5 SPEC. ISS.), 868883. https://doi.org/10.1016/j.worlddev.2005.04.022

Greenwood, M. R. (2002). Ethics and HRM: A review and conceptual analysis. Journal of Business Ethics, 36(3), 261-278. https://doi.org/10.1023/A:1014090411946

GRI. (2014). G4 Sustainability Reporting Guidelines. Global Reporting Initiative. Amsterdam.

Guerci, M., \& Pedrini, M. (2014). The consensus between Italian HR and sustainability managers on HR management for sustainability-driven change - towards a "strong" HR management system. The International Journal of Human Resource Management, $25(13), 1787-1814$. https://doi.org/10.1080/09585192.2013.860388 
Hameed, I., Riaz, Z., Arain, G. A., \& Farooq, O. (2016). How do internal and external CSR affect employees' organizational identification? A perspective from the group engagement model. Frontiers in Psychology, 7(MAY), 788. https://doi.org/10.3389/fpsyg.2016.00788

Harry, W. (2014). The relevance of the vision of sustainability to HRM practice. In I. Ehnert, W. Harry, \& K. J. Zink (Eds.), Sustainability and Human Resource Management: Developing Sustainable Business Organizations (pp. 401-419). Berlin/Heidelberg, Germany: Springer.

Haugh, H. M., \& Talwar, A. (2010). How do corporations embed sustainability across the organization? Academy of Management Learning and Education, 9(3), 384-396. https://doi.org/10.5465/AMLE.2010.53791822

Hirsig, N., Rogovsky, N., \& Elkin, M. (2014). Enterprise Sustainability and HRM in Small and Medium-Sized Enterprises. In: Sustainability and Human Resource Management (pp. 127-152). Springer, Berlin, Heidelberg.

Ho, L. C. J., \& Taylor, M. E. (2007). An empirical analysis of triple bottom-line reporting and its determinants: Evidence from the United States and Japan. Journal of International Financial Management and Accounting, 18(2), 123-150. https://doi.org/10.1111/j.1467-646X.2007.01010.x

Hur, W. M., Moon, T. W., \& Choi, W. H. (2019). When are internal and external corporate social responsibility initiatives amplified? Employee engagement in corporate social responsibility initiatives on prosocial and proactive behaviors. Corporate Social Responsibility and Environmental Management, 26(4), 849-858. https://doi.org/10.1002/csr.1725

Ingwe, R., Okoro, J., \& Ukwayi, J. K. (2010). The New Scramble for Africa: How Large-scale Acquisition of Sub-Saharan Africa's Land by Multinational Corporations and Rich Countries Threatens Sustainable Development. Journal of Sustainable Development in Africa, 12(3), 28-50.

Insch, G. S., Moore, J. E., \& Murphy, L. D. (1997). Content analysis in leadership research: Examples, procedures, and suggestions for future use. The Leadership Quarterly, 8(1), 1-25. https://doi.org/10.1016/S1048-9843(97)90028-X

Ives, C. D., Freeth, R., \& Fischer, J. (2020). Inside-out sustainability: The neglect of inner worlds. Ambio, 49(1), $208-217$. https://doi.org/10.1007/s13280-019-01187-w

Illgar, M. Z., \& ilgar, S. C. (2013). Nitel Bir Araştırma Deseni Olarak Gömülü Teori. İstanbul Sabahattin Zaim Üniversitesi Sosyal Bilimler Dergisi, 197247.

Jackson, A., Boswell, K., \& Davis, D. (2011). Sustainability and Triple Bottom Line Reporting - What is it all about? International Journal of Business, Humanities and Technology, 1(3), 55-59.

Järlström, M., Saru, E., \& Vanhala, S. (2016, August 30). Sustainable Human Resource Management with Salience of Stakeholders: A Top Management Perspective. Journal of Business Ethics. Springer Netherlands. https://doi.org/10.1007/s10551-016-3310-8

Kağnıcıoğlu, D., \& Etci, H. (2019). Özel Sektörde Çalışan Y Kuşağının Sendikal Algısı. Çalışma ve Toplum, 62(3), 1787-1822. Retrieved from http://www.calismatoplum.org/sayi62/kagnicioglu.pdf

Kira, M. (2003). From good work to sustainable development: human resource consumption and regeneration in the post-bureaucratic working life. Doctoral Dissertation. Royal Institute of Technology, Stockholm, Sweden.

Klein, J. A. (2004). True Change: How Outsiders on the Inside Get Things Done in Organizations. San Francisco: John Wiley \& Sons.

Kramar, R. (2014). Beyond strategic human resource management: is sustainable human resource management the next approach? The International Journal of Human Resource Management, 25(8), 1069-1089. https://doi.org/10.1080/09585192.2013.816863

Krippendorff. (2004). Content Analysis An Introduction to Its Methodology (Second Edi). Thousand Oaks, California: SAGE Publications.

Kuzey, C., \& Uyar, A. (2017). Determinants of sustainability reporting and its impact on firm value: Evidence from the emerging market of Turkey. Journal of Cleaner Production, 143, 27-39. https://doi.org/10.1016/j.jclepro.2016.12.153

Lees, S. (1997). HRM and the legitimacy market. International Journal of Human Resource Management, 8(2), $226-243$. https://doi.org/10.1080/09585199700000050

Lis, B. (2012). The Relevance of Corporate Social Responsibility for a Sustainable Human Resource Management: An Analysis of Organizational Attractiveness as a Determinant in Employees' Selection of a (Potential) Employer. Management Revue, 23(3), $279-295$. https://doi.org/10.5771/0935-9915-2012-3-279

Mak, A., Cheung, L., Mak, A., \& Leung, L. (2014). Confucian thinking and the implications for sustainability in HRM. Asia-Pacific Journal of Business Administration, 6(3), 173-189. https://doi.org/10.1108/APJBA-02-2014-0029

Mariappanadar, S. (2003). Sustainable human resource strategy: The sustainable and unsustainable dilemmas of retrenchment. International Journal of Social Economics, 30(8), 906-923. https://doi.org/10.1108/03068290310483779 
Mariappanadar, S. (2012). The harm indicators of negative externality of efficiency focused organizational practices. International Journal of Social Economics, 39(3), 209-220. https://doi.org/10.1108/03068291211199378

Mariappanadar, S., \& Kramar, R. (2014). Sustainable HRM : The synthesis effect of high performance work systems on organisational performance and employee harm. Asia-Pacific Journal of Business Administration, 6(3), 206-224. https://doi.org/10.1108/APJBA-03-2014-0039

Marpa, E. P., \& Juele, M. H. R. (2016). Environmental Awareness and Practices among High School Students: Basis for Disaster Preparedness Program. In Applied Mechanics and Materials, 848, 240-243. https://doi.org/10.4028/www.scientific.net/amm.848.240

Mazur, B. (2015). Sustainable Human Resource Management. The attempt of holistic approach. Ekonomia i Zarządzanie, 7(2), 7-12. https://doi.org/10.12846/j.em.2015.02.01

Muster, V., \& Schrader, U. (2011). Green Work-Life Balance: A New Perspective for Green HRM. German Journal of Human Resource Management, 25(2), 140-156. https://doi.org/10.1177/239700221102500205

Neuman, L. H. (2007). Basic of Social Research Qualitative and Quantitative Approaches (2 edition). Boston: Pearson/Allyn and Bacon.

Neumayer, E. (2011). Sustainability and Inequality in Human Development. UNDP-HDRO Occasional Papers No. 2011/4. Retrieved from https://ssrn.com/abstract=2351453

OSHA. (2016). Sustainability in the Workplace Worker Safety and Health. Washington. Retrieved from https://www.osha.gov/sustainability/docs/OSHA_sustainability_paper.pdf

Paillé, P., Chen, Y., Boiral, O., \& Jin, J. (2014). The Impact of Human Resource Management on Environmental Performance: An Employee-Level Study. Journal of Business Ethics, 121(3), 451-466. https://doi.org/10.1007/s10551-013-1732-0

Palaz, S., \& Poyraz, O. (2019). Gençlerin Sendikal Algı ve Tutumları Üzerine Bir Araştırma. Yönetim ve Ekonomi Araştırmaları Dergisi, 17(2), 5973. http://dx.doi.org/10.11611/yead.553284

Parsa, S., \& Kouhy, R. (2008). Social reporting by companies listed on the alternative investment market. Journal of Business Ethics, 79(3), 345360. https://doi.org/10.1007/s10551-007-9402-8

Prichard, C., Jones, D., \& Stablein, R. (2004). Doing Research in Organizational Discourse: The Importance of Researcher Context. In D. Grant, C. Hardy, C. Oswick, \& L. Putnam (Eds.), The Sage Handbook of Organizational Discourse (pp. 213-236).

PwC (PricewaterhouseCoopers). (2011). Building for the future Annual Report. London. Retrieved from https://www.pwc.co.uk/assets/pdf/pwcuk-2011-annual-report.pdf

Renwick, D. W. S., Jabbour, C. J. C., Muller-Camen, M., Redman, T., \& Wilkinson, A. (2016). Contemporary developments in Green (environmental) HRM scholarship. The International Journal of Human Resource Management, 27(2), 114-128. https://doi.org/10.1080/09585192.2015.1105844

Rompa, I. (2011). Explorative research on Sustainable Human Resource Management. Master's Thesis. University of Amsterdam.

Savaneviciene, A., \& Stankeviciute, Z. (2017). Smart Power as A Pathway for Employing Sustainable Human Resource Management. Inzinerine Ekonomika-Engineering Economics, 28(2), 198-206. https://doi.org/10.5755/j01.ee.28.2.17645

Senna, J., \& Shani, A. B. (2009). Creating sustainable work systems: Developing social sustainability: In P. Docherty, M. Kira, \& A. B. R. Shani (Eds.), Creating Sustainable Work Systems: Developing Social Sustainability (pp. 84-100). Routledge. https://doi.org/10.4324/9780203890028

Sivamoorthy, M., Nalini, R., \& Kumar, C. S. (2013). Environmental Awareness and Practices among College Students. International Journal of Humanities and Social Science Invention, 2(8), 11-15.

Stewart, F. (2014). Sustainability and Inequality. Development (Basingstoke), 57(3-4), 344-361. https://doi.org/10.1057/dev.2015.1

Tabatabaei, S. A. N., Omran, E. S., Hashemi, S., \& Sedaghat, M. (2017). Presenting sustainable hrm model based on balanced scorecard in knowledge-based ICT companies (The case of Iran). Economics and Sociology, 10(2), 107-124.

Tarquinio, L., Raucci, D., \& Benedetti, R. (2018). An investigation of Global Reporting Initiative performance indicators in corporate Sustainability Reports: Greek, Italian and Spanish evidence. Sustainability (Switzerland), 10(4), 897. https://doi.org/10.3390/su10040897

Vanderstraeten, A. (2015). The HRM Cockpit. An instrument for developing and evaluating sustainable HRM in an organization. In Sustainable HRM and Employee Well-Being, Proceedings., 1-27.

Vihari, N. S., \& Rao, M. K. (2018). Antecedents and Consequences of Sustainable Human Resource Management: Empirical Evidence from India. Jindal Journal of Business Research, 7(1), 61-85. https://doi.org/10.1177/2278682117754015 
Wagner, M. (2011). Environmental Management Activities and Sustainable HRM in German Manufacturing Firms - Incidence, Determinants, and Outcomes. German Journal of Human Resource Management, 25(2), 157-177.

Wagner, M. (2013). “Green” Human Resource Benefits: Do they Matter as Determinants of Environmental Management System Implementation? Journal of Business Ethics, 114(3), 443-456. https://doi.org/10.1007/s10551-012-1356-9

Weber, R. P. (1990). Basic Content Analysis. Sage Publications (Second edi). Newbury Park, CA: Sage Publications.

Welford, R. (2016). Corporate Environmental Management 3: Towards sustainable development. Abingdon: Routledge.

Wilcox, T. (2006). Human resource development as an element of corporate social responsibility. Asia Pacific Journal of Human Resources, 44(2), 184-196. https://doi.org/10.1177/1038411106066395

Wilkinson, A., Hill, M., \& Gollan, P. (2001). The sustainability debate. International Journal of Operations and Production Management, 21(12), 1492-1502. https://doi.org/10.1108/01443570110410865

Wong, M. M. L. (2017). Stratified sustainability in human resource management in Japanese subsidiaries in Hong Kong. Asian Journal of Business Ethics, 7(2), 151-175. https://doi.org/10.1007/s13520-017-0082-x

Yıldırım, A., \& Şimşek, H. (2016). Nitel Araştırma Yöntemleri (10th ed.). Ankara: Seçkin Yayıncılık.

Younis, F., \& Chaudhary, M. A. (2019). Sustainable Development : Economic , Social , and Environmental Sustainability in Asian Economies, 15, 87114.

Zaugg, R., Blum, A., \& Thom, N. (2001). Sustainability in human resource management. Evaluation Report. Survey in European Companies and Institutions. Arbeitsbericht des Instituts für Organisation und Personal der Universität Bern und des eidgenössischen Personalamtes.

Zink, K. J. (2014). Designing sustainable work systems: The need for a systems approach. Applied Ergonomics, 45(1), 126-132. https://doi.org/10.1016/j.apergo.2013.03.023 